\title{
Belonging and participation in liminality: Unaccompanied children in Finland and Sweden
}

Mervi Kaukko and Ulrika Wernesjö

\section{Linköping University Post Print}

\section{Tweet}

N.B.: When citing this work, cite the original article.

Original Publication:

Mervi Kaukko and Ulrika Wernesjö, Belonging and participation in liminality: Unaccompanied children in Finland and Sweden, 2016, Childhood.

http://dx.doi.org/10.1177/0907568216649104

Copyright: SAGE Publications (UK and US)

http://www.uk.sagepub.com/home.nav

Postprint available at: Linköping University Electronic Press

http://urn.kb.se/resolve?urn=urn:nbn:se:liu:diva-129034 


\title{
Belonging and participation in liminality: Unaccompanied children in Finland and Sweden
}

\author{
Mervi Kaukko \\ University of Oulu, Finland \\ Ulrika Wernesjö \\ Linköping University, Sweden
}

\begin{abstract}
This article investigates children's participation and sense of belonging from the perspective of unaccompanied children, based on two qualitative research projects with unaccompanied children in Sweden and Finland. The results show that the unaccompanied children's own understanding of their participation and belonging in different positions was fluid; for instance, the borders between childhood and adulthood, and striving for independence or wanting to be cared for by adults were flexible, allowing the children's movement within and between the categories.
\end{abstract}

\section{Keywords}

Age, belonging, gender, Nordic context, participation, unaccompanied children

\section{Context: Unaccompanied children in Finland and Sweden}

The voices of unaccompanied asylum-seeking and refugee children have raised increasing attention in recent childhood studies (cf. Wernesjö, 2012; De Graeve and Bex, 2015; Ní Raghallaigh and Sirriyeh, 2015; Vervliet et al., 2015). The increasing numbers of unaccompanied children arriving in Europe show that the situation of unaccompanied children, as well as their care and reception in the receiving country, remains a very relevant topic for study. The children concerned have to build their identities while encountering multiple liminal stages; they are moving from one country to another, from childhood to adulthood, while negotiating their identities and belonging according to the (assumed) requirements of the new circumstances. Because of the adversities that unaccompanied children face, they are often positioned in categories such as vulnerable and traumatized (Stretmo, 2014; see also Malkki, 1992). However, these figurations rarely take into account how the unaccompanied children position themselves (Wernesjö, 2012). Furthermore, the children constantly encounter well-known public discourses of disputes over age, untrustworthiness and the groundlessness of asylum claims (Stretmo, 2014; Watters, 2008). These images reduce unaccompanied children to stereotypes and thus fail to take into account the heterogeneity among them. However, while acknowledging the diversity in experiences and social positions within this category of children, we argue that most of them also have something in common: their shared experiences of separation, migration and the asylum process, as well as the similar position they occupy in the receiving country.

The aim of this article is to investigate the participation of unaccompanied asylum-seeking and refugee children in their living units in Finland and Sweden, paying attention to how they position themselves in terms of age, gender and status and how they view their participation in relation to a sense of belonging. The article is based on two qualitative research projects: Study 1 explores unaccompanied asylum-seeking girls' perspectives on children's participation during the asylum process in Finland (Kaukko, 2015), and Study 2 focuses on unaccompanied refugee children and youngsters' negotiations of belonging in Sweden (Wernesjö, 2014). We use the term asylum-seeker for those who are awaiting a decision on their asylum applications and refugees for those who have been granted residency after applying for asylum. The results show that while categories such as age and gender were very fluid, multi-layered and complex, the children's shared experiences can inform the development of good practice for the accommodation and care of unaccompanied children.

Finland and Sweden are neighbouring countries with many similarities in the reception and care of unaccompanied children. The number of such children, however, is vastly different (see below). Although the Nordic countries invest significantly in integration practices (Migrant Integration Policy Index [MIPEX], 2015), the success of the practices is often measured in terms of participation in education, internship or work (e.g. Celikaksoy and Wadensjö, 2015). Thus, there is a gap in research concerning how unaccompanied children in the Nordic countries experience participation and the notions of belonging in their everyday lives.

\section{Context: Unaccompanied children in Finland and Sweden}

From an international and historical perspective, Finland and Sweden both have a relatively short history of significant immigration. However, Sweden has a longer history of refugee immigration, while it is a more recent phenomenon in Finland (Hentilä et al., 2002), and Sweden receives larger numbers of asylum-seekers, particularly 
unaccompanied children than Finland. To illustrate, 196 unaccompanied children arrived in Finland in 2014 and 7049 in Sweden (Finnish Immigration Service, 2015; Swedish Migration Board, 2015a). ${ }^{1}$ During the autumn of 2015, there was an increase in asylum-seekers coming to Europe to seek protection from ongoing and devastating wars and conflicts: up to 30 November 2015, the number of unaccompanied asylum-seeking children increased to 32,180 in Sweden and to 2770 in Finland (Finnish Immigration Service, 2015; Swedish Migration Board, 2015b).

The asylum process and reception system in Finland and Sweden are quite similar and regulated by the national legislations, ${ }^{2}$ European Union (EU) treaties ${ }^{3}$ and international conventions. ${ }^{4}$ In both countries, unaccompanied asylum-seeking children are placed in reception centres on arrival and are thereafter referred to municipalities that provide housing and care for them, often in group homes or foster families (if the child does not have relatives whom they can live with). Furthermore, a guardian ad litem is assigned to act as the child's custodian until they reach the age of majority. Perhaps the most significant difference between the systems in Finland and Sweden is that the Swedish system draws on the child welfare legislation, more particularly the Swedish Socialtjänstlagen [Social Services Act] (2001:453), whereas the unaccompanied children in Finland are not directly under the Finnish Child Welfare Act like other children in care (Männistö, 2011). The best interest of the child is the guiding principle of policies concerning unaccompanied children in both countries. It has been questioned, however, whether the principle is put into practice sufficiently for asylum-seeking children (Eastmond and Ascher, 2011; Hetemäki, 2013). In Finland, the police are involved in the initial reception of unaccompanied children. This is not the case in Sweden, where the municipalities are responsible for providing housing and care for the child (Finnish Immigration Service, 2015; Prop. 2012/13:162, 2013).

Although the importance of children's participation is widely acknowledged, previous research shows that participation could be challenging for unaccompanied children, and the connection between good practice and a sense of participation and belonging is poorly researched. For instance, research from Sweden has shown that unaccompanied children's participation is restricted during the asylum-seeking process in the reception and care system (e.g. Backlund et al., 2012; Gustafsson et al., 2012; Keselman et al., 2010; Lundberg and Dahlquist, 2012; Stretmo and Melander, 2013), and studies have shown that the unaccompanied children experience a lack of power in the decision-making that concerns them (Gustafsson et al., 2012). Gustafsson et al. (2012) point to the paradox that restrictions of participation are embedded within a care and protection system that encourages independence and freedom of choice. Research in Finland has shown that the unaccompanied children view relevant participation in a way that differs from the most common definitions, such as Article 12 of the United Nations Convention on the Rights of the Child (CRC; United Nations, 1989); Study 1 shows that unaccompanied children often argue that the stability and the right to be protected by surrounding adults overweigh the right to have their own voices heard (Kaukko, 2015). While participation for unaccompanied children has been investigated in research to some extent, questions of belonging have, with a few exceptions (e.g. De Graeve, 2015; Kohli, 2011; Wernesjö, 2014), not raised much attention in the research.

Boyden (2001) notes that children's participation in contexts of forced migration tends to be restricted due to manifestations of power and adult perspectives on the child's best interest. Moreover, challenges in implementing the CRC for refugee children in families in Norway, and especially the right to participate, are, according to Lidén and Rusten (2007), due to the demands of the asylum system. Barry (2002: 251-252) argues that the mismatch between the protection and participation of children in care could damage their long-term development in two ways: too high expectations and too much independence at an early age might curb the child's willingness to take responsibility for their own life later. However, a more typical problem with unaccompanied asylum-seeking children is that their acquired capabilities may be conceived as having no value or use in the care system.

While the reception of unaccompanied children is rapidly changing in both Finland and Sweden, there is a gap in the research on how these children experience participation and belonging in their day-to-day lives. This knowledge, we suggest, could be utilized for improving the care of such children. Hitherto, research has not sufficiently acknowledged how the challenging situation of these children can be seen as a resource and not merely a burden: the sense of belonging may be strengthened by the awareness that other children have had similar experiences in the past, and the common goal and waiting for the 'real life' to start after the asylum process further strengthen such a feeling (Kaukko, 2015).

\section{Conceptualizing unaccompanied childhood}

In this article, we attempt to investigate how unaccompanied children view participation; how they position themselves in terms of age, gender and status; and how they view their participation in relation to a sense of belonging. In doing so, we use an intersectional approach in order to acknowledge the way in which social categories and systems of power intersect and shape the children's experiences and the positions available for them (e.g. Krekula et al., 2005; Lykke, 2010; Yuval-Davis, 2006). Although we acknowledge the heterogeneity and fluidity of these social categories, it is necessary to consider what childhood and migration studies have to offer when conceptualizing unaccompanied childhoods. 
In line with the new 'orthodoxy' of childhood studies (Alanen, 2015), we too stress the significance of investigating age and childhood as socially constructed and, thus, as changing, contextual and articulated with other social differences (James and Prout, 1997). Such an understanding of age challenges discourses of children as 'adults-to-be', or as 'becomings', emphasizing that children are resourceful, active social agents in their own right instead of being silent objects or 'passive beneficiaries' (James and Prout, 1997). The focus is thus on seeing children's ability to participate and act, as well as to explore how children's participation can be enabled or restricted in different ways (James and James, 2008: 94).

Regardless of how resourceful and resilient unaccompanied children are, the social, historical and cultural contexts pose some rather tangible challenges to their participation. Refugees and migrants are often pathologized and conceived of as being in a 'deplorable state', according to Kibreab (1999), because of the assumption that there are 'natural' places in which people belong and from which they derive their identities, and 'outside that physical context they are treated as strangers or as non-members of the host society with conditions that attend "otherness"' (p. 387), until full membership is attained (see also Malkki, 1992). As long as displaced children, such as unaccompanied children, have left their place of 'origin' and have not yet been accepted as full members in the society, they can be described as being in a 'liminal' situation. Liminality, as defined by Turner (1974), is a phase of life with 'few (though sometimes these are the most crucial) of the attributes of either the preceding or subsequent profane social statuses or cultural states' (p. 57). In the case of our studies, the current phase for the children had very few familiar elements with their pasts or the perceived futures. The liminality can become evident through more or less apparent structures highlighting the difference between the 'real world' and the 'liminal', for example, the spatial segregation of the living units from the rest of the society. This liminality, combined with the children's age, separation from their families and status as asylum-seekers or refugees, means that their space for action is restricted and that they are often objects, not subjects of decision-making, that is, regarding their asylum application, living situation or family reunion. However, while the childhood of unaccompanied children is formative, their migration as well as how they spend their time in the liminal situation can be transformative; they are not automatically victims of their position, but can also use challenging life situations to their benefit in developing creative strategies to cope and participate.

By investigating unaccompanied children's participation, this article also interrogates the significance of participation for their sense of belonging. In so doing, we draw on intersectional perspectives on belonging that acknowledge fluidity and process in the construction of belonging(s), thus challenging simplistic and essentialist notions of ethnic and national collectivities (e.g. Yuval-Davis, 2011). Belonging can be defined as a sense of ease among the people around you, and the ability to act and to participate in a social context in a respected and acknowledged manner (May, 2011). The question of belonging may become a pressing issue for all individuals, depending on the situation and context, and not least for unaccompanied children, due to their experiences of (forced) migration and separation from parents and other family members. In addition, the intersectionality of social categories such as gender, ethnicity and age is of significance for how the participant's claims of belonging are negotiated by themselves and others (e.g. Wernesjö, 2014; Yuval-Davis, 2011), as well as for how the success of this negotiation process promotes or restricts participation (Kaukko, 2015). Denied claims of belonging and the lack of recognition of participation have been connected to social exclusion as well as individual and societal problems among asylum-seeking children (Sporton et al., 2006). Sporton et al. (2006: 213) suggest that negotiation of one's own position is not a simple process in the 'liminal' phase of refugee children's lives in general, and the situation of unaccompanied children may become even more complicated, since research shows that there is no one who takes up the parenting role in the care of them (e.g. De Graeve and Bex, 2015; Stretmo, 2014).

\section{The studies}

The two research projects of this article considered the notions of participation and belonging from the abovementioned perspectives. The data in the first study were gathered as a part of participatory action research project, in which 12 unaccompanied asylum-seeking girls - aged 8-17 - participated in developing meaningful free-time activities at two living units in a Finnish reception centre. After the project, 11 of the girls were interviewed in semistructured, thematic interviews focusing on themes such as participation and children's rights. The second study was based on qualitative interviews with unaccompanied children and youngsters who had been granted residency in Sweden. The interviews were thematic and focused on different aspects of the participants' everyday lives, social relationships and sense of belonging. In total, 17 children and youngsters were interviewed, of which $11-9$ boys and 2 girls, aged 16-19 years - are included within the limitations of this article. At the time of the study, the participants were living in group homes for unaccompanied children or had recently moved to more independent living units with some degree of assistance from care workers. ${ }^{5}$

Both studies have undergone ethical evaluation. The Swedish study underwent an ethical evaluation by the local Ethical Vetting Board, while the Finnish study was evaluated at the university level. The participants in both studies were given information about the study, both verbally and in writing. In addition, permission from the children, and their guardians, ${ }^{6}$ was granted before starting of both projects. The managers and practitioners at the 
reception centre granted permission for the first study, whereas in Study 2 these resources granted permission more informally by acting as gatekeepers. The participants were given the opportunity to read and make comments on the transcripts, and Study 1 also included participatory data analysis with all the girls. In order to protect the personal integrity of the participants, we have given them random pseudonyms.

Next, we present the findings of our study, focusing on how the participants position themselves in terms of age, gender and status and how they view their participation in relation to a sense of belonging.

\section{Age, (in)dependence and status}

The children in our studies saw childhood and adulthood to some extent as distinctive categories of difference, but at the same time, the distinction between the two was constantly problematized and destabilized. The children saw their own positions as negotiable and situational within a continuum between childhood and adulthood, as the examples below demonstrate.

The girls in the Finnish study joked about what it would be like if they could set their own rules: sweets and cakes for food and no curfews. However, they noted that as children and asylum-seekers, they need adults with knowledge of the receiving country in order to survive and to learn how to live within the new circumstances. Hence, they positioned themselves as 'becomings', who needed to learn more about responsibilities and rights before the next stage of their life starts.

In contrast to such a positioning, others expressed that they, in a sense, had been 'reversed' back into childhood after arriving in the reception country. The migration process involves a certain degree of agency and can be seen as an attempt to make a better life for oneself. Moreover, some of the children have had more agency and responsibilities in the past, such as taking care of, and providing for, themselves and other family members:

Yes, we start from early on to help mother with domestic work; sometimes boys help fathers too. Then you become responsible. But here, it feels that 15 -year-olds still behave like children because they are always called children. (Akia)

With regard to her experiences of having responsibilities, Akia considers herself to be more mature than her Finnish peers. She was critical of being positioned as a child, which for her meant not being responsible or being entitled to make independent decisions. Other participants, on the contrary, said that they should not make decisions for themselves and that adults should care for them, due to their young age:

I don't think children should be allowed to decide on things. School, for example. If someone doesn't want to go to school, she shouldn't decide. The adults have to help in that situation. You have to consider so many things (in decisions like that), like the age of the child. (Nawaal)

Nawaal associates childhood with immaturity and argues that children, due to their young age and other qualities (referred to here as 'so many things' and elaborated later to include life-experiences and wisdom), are unable to make educated decisions by themselves. From her perspective, adults are the ones who are able to take care of children's best interests. Yet, the excerpt also illustrates the fluidity of the age categories, and more particularly how the children may change positions during the course of the interview. When Nawaal argues that children are not mature enough to make certain decision, she is at the same time positioning herself as mature and knowledgeable, that is, as more of an adult than a child. Hence, what Nawaal says here could be interpreted as if she is moving between the age categories.

In order to understand how the liminality affected the children, it is important to note the differences in status between the participants in the two studies. The girls who were still asylum-seekers were living in an uncertain situation. For them, the living unit was a stopping-place where they awaited the decision of their asylum application - whether they would be accepted or rejected. After having been granted residency, as the children in the Swedish study had been, some of the uncertainty disappears. However, there are still some uncertainties some that are specific to unaccompanied children, such as the hopes of finding or being reunited with family members, and some connected to childhood and adolescence that they, thus, share with others their same age.

\section{Positionings of age and (in)dependence}

In both studies, the children referred back to experiences of conflicts with staff in the living unit: regarding food, cleaning and cooking schedules and decision-making, to name a few examples. Tensions such as these are one example of how the children's positions are negotiated in everyday interaction with practitioners and how the positions change in relation to the social dynamics in the living units. As we have illustrated above, the children positioned themselves and others their same age along the continuum of age and, consequently, dependence/independence. In the subsequent analysis, we identify three ways the children positioned themselves in relation to the staff and situation at the living unit. 
The first position is characterized by neither problematizing being dependent on adults nor questioning the asymmetrical power relationship between the children and practitioners. For instance, Abdikarim said he was content with the care he was given and the situation at the living unit:

I don't have any problems. If I need to go somewhere and there is no bus going there, when I need a ride, I ask him (his contact person). If I need to use the phone to call a friend, I ask him first. (Abdikarim)

'I don’t have any problems', he said on a number of occasions during the interview. He turned to staff for practical issues and considered the living unit to be a safe place to be for children like himself before moving on to a more independent living arrangement. In the process of becoming more independent, children can use practitioners as a resource to get what they need, scaffolding their own participation.

The second position involved challenging the power relation between adults and children and demanding more participation and independence. This was connected in particular with participants who were approaching - or had reached - the age of majority or children who had previously had duties and responsibilities connected to adulthood. Khalil, who looked forward to moving to an independent living arrangement, says,

We don't have any freedom here. If we listen to music, they (the staff) tell us to 'please turn down the volume' if we [...] and the food, sometimes they make good food, sometimes they don't, then we make our own food. If we ask for something, sometimes we get a 'yes', but most often we get negative answers. (Khalil)

In the excerpt, Khalil raises different ways in which he is restricted by the staff and the rules at the living unit. Although Khalil acknowledged the need for some rules, he was critical of many of them and, in particular, the way in which they were decided on and enforced. From his perspective, the rules lived a life of their own. One of the girls, Julie, argued that the staff had restricted her from doing things she would like to do, and would be able to do for herself, by saying there is a minimum age limit. Thus, she positions herself as more of an adult when it comes to practical tasks, just as Nawaal also did. However, she also noted that because of her young age and vulnerability, she and others in similar situations need adults who spend time with them and give emotional support to a greater extent than she is given in the present.

Finally, there is a third position where the children were critical of the care they were given as children. Hence, they positioned themselves as vulnerable and dependent on adults and felt that their needs are not adequately considered. In the interview with Shaoib, he described feeling vulnerable and that his needs for medical attention were not taken care of by the practitioners. Moreover, he wanted to live in a family instead of a group home since living with a family is the 'normal' thing to do for someone his own age - but his request was denied. Similarly to Abdikarim, he positions himself as a child and, as such, is in need of care from adults. However, instead of being content, he is critical of the care given and argues that his best interests are not taken into account by the adults around him.

As the following shows, the children wanted to participate in decision-making, yet there was no mutual understanding on the quantity and quality of participation they should be allowed. As one girl in the Finnish study argued,

Children should at least be asked what they want, whether they would like to do something or not. If they are forced, if the decision is made elsewhere and you have to do it even if it is annoying; that is not right. (Binti)

Those who did strive for making their own decisions wanted to be included in decision-making or, at least, to be informed about the reasons for the rules at the living unit. This is in line with Khalil's views, who in the previous section argued that staff restricted him and did not inform him adequately about the reasons for the rules. At the living unit where he stayed, the children were invited to participate in decision-making by putting suggestions in a box that were later decided on at a 'house meeting', where both staff and the children living there participated. According to Khalil, however, the practitioners had the last say, which is also what the girls in the Finnish study argued about their monthly unit meetings: although the children were encouraged to voice concerns and ask questions, in reality it more resembled a practitioner's monologue than a dialogue.

To conclude, we suggest that there is fluidity in the desired level of participation from the children's perspectives in our studies: from settling for having restricted (observable) participation, to emphasizing the importance of being given information, to participating on a practical level and to being able to exercise individual decision-making (e.g. Hart, 1992). Moreover, these levels are connected to the ways in which the children positioned themselves along the continuum of childhood and adulthood. Neither age positions nor the desired levels of participation were fixed, but rather changed depending on the situation.

\section{Gender and belonging - The living unit as a gendered place}


The influence the children's age and status had on their participation was to some extent gendered. The girls in the Finnish study connected participation in the everyday life in the living unit with practical work and, most often, with chores which are traditionally seen as 'women's work'. In the Swedish study, however, there were fewer discussions of the gendered division of domestic chores. Rather, the children talked about the domestic chores that they liked or disliked to do, which they already knew how to do and which they had to learn before moving to independent living. Although we are sceptical about a dichotomous portrayal of the gendered positions of different cultures and aware of the gendered stereotypes in Sweden and Finland too, some of the children came from comparatively conservative rural areas in which appropriate roles of boys and girls may differ from what the children experience in the living unit and in Finnish or Swedish society at large. Both studies showed that the children viewed Finland and Sweden as gender-equal societies compared to their countries of origin. Especially in the Finnish study, the girls were curious about the positions of women and men in the Nordic countries ('Can women be police?' 'Is it normal for men to wash windows?') and wanted to benefit from living in a country with relatively good gender equality. The children in both studies appeared to be equally determined to benefit from choices they would have in the future if they were accepted to stay in Finland and Sweden, such as the possibility to have free education.

As shown above, the image of Finland and Sweden as more gender-equal societies especially influenced the girls' aspirations for the future. While the future was seen as an era of more gender equality, gender was given meaning in the living unit, influencing the power dynamics and (un)safety in the here-and-now of the children. For instance, a girl in the Swedish study talked about having to live with boys she was not related to as something she was unused to from her country of origin and which, therefore, made her uncomfortable:

Sometimes you feel a bit scared and worried, when the boys are rowdy then you feel a bit worried [...] It's not nice, you know, it is uncomfortable sometimes. A boy lives opposite my room, so I can't go out (of my room) directly in the morning, so it is not a good thing, that boys and girls live together like this. (Samira)

As the excerpt shows, Samira tries to avoid potentially uneasy encounters by restricting her movements in the living unit. Similarly, a girl in the Finnish study said that she had to wear a veil everywhere because she did not know which parts of the building were monitored by cameras, that is, where she could be seen by men. While she referred to religious reasons, other girls told Kaukko that their reluctance to interact with men was due to past experiences of being subjected to violence and abuse from men.

In contrast to the girls, who talked about living together with boys, the boys rarely talked about the girls. We suggest that in this regard, it is important to consider the social dynamics in the living units. The vast majority of unaccompanied children who arrive in Sweden and Finland are boys; girls, thus, constitute a minority in the living units, which was also the case in our studies. In line with the discussion of some girls expressing that they felt uncomfortable and afraid because of rowdy boys or because of previous experiences, we suggest that the girls become more aware of gender and gender differences because they had been placed in a very boy-dominated living arrangements, while young masculinity comes to constitute the norm. In this regard, young masculinity becomes a privileged position and is, thus, unmarked (e.g. Pease, 2010), while other positions are subordinated. To put it simply, the girls are to some extent forced to relate to the boys and find their positions among them, while the opposite is not always the case. Thus, the girls' movements in the living units are at times limited, both physically and mentally, which may also affect their sense of security and belonging.

\section{Concluding discussion}

This article shows that regardless of the differences in research design, focus, context and participants between the two studies, there are similarities in the ways belonging and participation are discussed among unaccompanied children in Finland and Sweden. This heterogeneous group of children - due to their status as asylum-seekers or refugees - become members of one and the same category 'unaccompanied children' and evidently share some experiences in how they encounter the care and reception system in the welfare states in which they have arrived. Nevertheless, these similarities should not be understood essentially, as being applicable to all unaccompanied children. The stories were fluid, which highlights the fact that the children's positions were not seen as simple or static, but were influenced by many factors depending on their situation. The children's positions changed in everyday interactions among the children and between children and adults, which is why adults need to listen carefully to what might be needed for each individual child in their everyday life. Smoothly functioning relations where children get the support they need and also the responsibilities they can handle are key to the children's sense of self-worth and belonging. Thus, based on the fluidity of the categories, on one hand, and the similarities in the children's experiences, on the other, we argue that the contextual similarities in the two countries contribute to understanding the children's experiences, rather than assuming that their experiences of participation and belonging depend solely on a membership in a category, such as asylum-seeking status or young age.

We have identified three ways in which the children positioned themselves in relation to age and participation in the living units. The first position refers to a situation in which children were content with having an 
asymmetrical power relation between the children and practitioners; reliable adults were seen as necessary resources to scaffold children's participation and to enable children to learn more about their situation. The second position meant challenging the power relation between adults and children in the living unit, arguing for more participation and independence. Finally, the third position applied in situations where children were critical of the care they were given; they argued that due to their childhood and asylum-seeking status, they required more support than they were given. Instead of more independence, they wanted to have more care and attention. In this regard, they make claims to participate in the discussion of how to improve the reception of unaccompanied children. In addition to age, gender and status intersect in these children's experiences and shape their positions in the living unit and the receiving country. Moreover, the liminality and temporality of the situation influenced the children's sense of belonging, that is, the 'sense of ease among the people around you' (May, 2011), which we suggest is essential for participation. Our findings are similar to Boyden's (2001), who notes that a sense of belonging can be challenging to achieve in a transient group, especially if the group has been brought together by a crisis. Coming from areas of civil war and disruption, unaccompanied children might not be able to trust people around them. Intersectional approaches contribute to the existing knowledge on unaccompanied children not only by highlighting the importance of focusing on the assumed trauma or victimhood of unaccompanied children but also by emphasizing the need to take into account not only other difficulties but also the strengths and resources of these children. Presenting the vulnerability or resilience of unaccompanied children as counterpoints is unhelpful, as evidently they may be both vulnerable and active agents depending on the situation. We argue that research, as well as the care of unaccompanied children, should question the dichotomous and fixed understanding of their positions by acknowledging that individuals are actively involved in shaping their own lives, even if the limitations of their realities may seem unsurpassable from an outside perspective.

To conclude, as we have argued, both Finland and Sweden have an urgent need to develop the reception and care of unaccompanied children in order to facilitate the participation of unaccompanied children and to address the changing situation. This research can inform practice by highlighting that childhood and adulthood are not simply distinctive categories of difference. Instead, this article shows how unaccompanied children move into and between positions, depending on the situation. Their positions are influenced not only by chronological age but also by past experiences, which should be acknowledged when organizing the reception and care of unaccompanied children. Moreover, the complementary relationship between children and adults can be a resource enabling children's participation. Nevertheless, the children's changing positionings do not take away the fact that from a legal perspective, they are children, and have children's rights, and should be protected as such.

\section{Funding}

This work was supported by the Finnish Cultural Foundation, Mannerheim League for Child Welfare and Finnish Multidisciplinary Doctoral Training Network on Educational Sciences (Study 1) and Children's Welfare Foundation Sweden (Study 2).

\section{Notes}

1. In 2014, in Finland, the approval rate for unaccompanied asylum-seeking children was 82\% (Björklund, 2015; Finnish Immigration Service, 2015), while the approval rate in Sweden was $75 \%$ in the first instance, that is, the Swedish Migration Board (2015a, 2015b).

2. In Finland, Aliens Act 2004/301, Section 5 and Reception Act 2011/746, Section 5. In Sweden, Aliens Act (2005:716), Act on the reception of asylum-seekers et al. 1994:137, among others.

3. Most importantly, the European Social Charter, The Charter of Fundamental Rights of the European Union which has provisions concerning children's right to Protection, Provision and Participation, Council Directive 2003/9/EC in which the minimum standards for the reception of unaccompanied children are defined.

4. Most importantly, the United Nations (UN) Convention of the Rights of the Child.

5. Four of the remaining participants had lived independently for a longer period of time and did not receive assistance from care workers to the same extent as the others. In addition, two of these participants had lived with relatives instead and, thus, had no experience of the living units discussed in this article.

6. In Sweden, permission from guardians was not asked since all the participants were over the age of 16 years. In Finland, all children's guardians were asked for permission.

\section{References}

Alanen L (2015) Are we all constructionists now? Childhood 22(2): 149-153.

Backlund Å, Eriksson R, von Greiff K, et al. (2012) Ensam och flyktingbarn: Barnet och socialtjänsten om den första tiden i Sverige. Report no. 2012:1. Tullinge: FoU Södertörn.

Barry M (2002) Minor rights and major concerns: The views of young research people in care. In: Franklin B (ed.) The New Handbook of Children's Rights. London: Routledge, pp. 239-253. 
Björklund K (2015) Unaccompanied refugee minors in Finland - Challenges and good practices in a Nordic context. Migration studies C26. Turku: Institute of Migration. Available at: http://www.migrationinstitute.fi/fi/node/1762.

Boyden J (2001) Children's participation in the context of forced migration. Participatory Learning and Action 42: $52-56$.

Celikaksoy A and Wadensjö E (2015) De ensamkommande flyktingbarnen och den svenska arbetsmarknaden. Report no. 2015:2. Stockholm: The Stockholm University Linnaeus Centre for Integration Studies (SULCIS) and Europeiska flyktingfonden. Available at: http://www.su.se/polopoly_fs/1.238803.1433429678!/menu/standard/file/De\%20ensamkommande\%20flyktin gbarnen\%20och\%20den\%20svenska\%20arbetsmarknaden\%20Aycan\%20\%C3\%87elikaksoy\%20och\%20Esk il\%20Wadensj\%C3\%B6.pdf.

De Graeve K (2015) Classed landscapes of care and belonging: Guardianships of unaccompanied minors. Journal of Refugee Studies. Epub ahead of print 11 August. DOI: 10.1093/jrs/fev011.

De Graeve K and Bex C (2015) Imageries of family and nation: A comparative analysis of transnational adoption and care for unaccompanied minors in Belgium. Childhood. Epub ahead of print 30 November. DOI: 10.1177/0907568215613421.

Eastmond M and Ascher H (2011) In the best interest of the child? The politics of vulnerability and negotiations for asylum in Sweden. Journal of Ethnic and Migration Studies 37(8): 1185-1200.

Finnish Immigration Service (2015) Unaccompanied minors who arrive to Finland. Available at: http://www.migri.fi/asylum_in_finland/applying_for_asylum/unaccompanied_minors_who_arrive_in_finland (accessed 14 December 2015).

Gustafsson K, Fioretos I and Norström E (2012) Between empowerment and powerlessness: Separated minors in Sweden. New Directions for Child and Adolescent Development 136: 65-77.

Hart RA (1992) Children's Participation: From Tokenism to Citizenship. Florence: UNICEF International Child Development Centre.

Hentilä S, Krötzl C and Pulma P (2002) Pohjoismaiden historia. Helsinki: Edita.

Hetemäki I (2013) Lapsen edun varmistaminen yksintulleiden alaikäisten turvapaikkaprosessissa. In: Seminar by UNHCR/UNICEF, Helsinki, 3 December.

James A and James A (2008) Key Concepts in Childhood Studies. London: SAGE.

James A and Prout A (1997) Constructing and Reconstructing Childhood: Contemporary Issues in the Sociological Study of Childhood, 2nd edn. London: RoutledgeFalmer.

Kaukko M (2015) Participation in and beyond liminalities. PhD thesis, University of Oulu, Oulu.

Keselman O, Cederborg A and Linell P (2010) 'That is not necessary for you to know!': Negotiation of participation status of unaccompanied children in interpreter-mediated asylum hearings. Interpreting: International Journal of Research and Practice in Interpreting 12(1): 83-104.

Kibreab G (1999) Revisiting the debate on people, place, identity and displacement. Journal of Refugee Studies 12(4): 384-410.

Kohli R (2011) Working to ensure safety, belonging and success for unaccompanied asylum-seeking children. Child Abuse Review 20(5): 311-323.

Krekula C, Närvänen AL and Näsman E (2005) Ålder i intersektionell analys. Kvinnovetenskaplig tidskrift 26(23): 81-94.

Lidén H and Rusten H (2007) Asylum, participation and the best interests of the child: New lessons from Norway. Children \& Society 21(4): 273-283.

Lundberg A and Dahlquist L (2012) Unaccompanied children seeking asylum in Sweden: Living conditions from a child-centered perspective. Refugee Survey Quarterly 31(2): 54-75.

Lykke N (2010) Feminist Studies: A Guide to Intersectional Theory, Methodology and Writing. New York: Routledge.

Malkki L (1992) National geographic: The rooting of peoples and the territorialization of national identity among scholars and refugees. Cultural Anthropology 7(1): 24-44.

Männistö Y (2011) Preface. In: Alanko S, Marttinen I and Mustonen H (eds) Lapsen etu ensin. Ykintulleet alaikäiset turvapaikanhakijat Suomessa [The Best Interest of the Child First. Unaccompanied Asylum-Seeking Children in Finland. All Our Children]. Helsinki: Yhteiset lapsemme Ry: 5-6.

May V (2011) Self, belonging and social change. Sociology 45(3): 363-378.

Migrant Integration Policy Index (MIPEX) (2015) Migration integration policy index. Available at: http://www.mipex.eu/key-findings (accessed 7 October 2015).

Ní Raghallaigh M and Sirriyeh A (2015) The negotiation of culture in foster care placements for separated refugee and asylum seeking young people in Ireland and England. Childhood 22(2): 263-277.

Pease B (2010) Undoing Privilege: Unearned Advantage in a Divided World. London: Zed Books.

Prop. 2012/13:162 (2013) Kommunalt mottagande av ensamkommande barn [Municipal reception of unaccompanied children]. 
Socialtjänstlagen [Social Services Act] (2001:453).

Sporton D, Valentine G and Nielsen KB (2006) Post conflict identities: Affiliations and practices of Somali asylum seeker children. Children's Geographies 4(2): 203-217.

Stretmo L (2014) Governing the unaccompanied child: Media, policy and practice. PhD thesis, Göteborg University, Gothenburg.

Stretmo L and Melander C (2013) Får jag vara med? Erfarenheter från ensamkommande barn och unga och arbetet med denna grupp. Report no. 2:2013, June. Göteborg: FoU i Väst/GR.

Swedish Migration Board (2015a) Om ensamkommande barn/Statistik [On unaccompanied minors/Statistics]. http:/www.migrationsverket.se/Andra-aktorer/Kommuner/Om-ensamkommande-barnoch-ungdomar/Statistik.html (accessed 18 April 2015).

Swedish Migration Board (2015b) Statistik/Ansökningar om asyl [Statistics/Applications for asylum]. Available at: http:/www.migrationsverket.se/download/ 18.7c00d8e6143101d166d1aab/1448974429957/Inkomna+ansökningar+om+asyl+2015++Applications+for+asylum+received+2015.pdf (accessed 15 December 2015).

Turner VW (1974) Liminal to liminoid, in play, flow, and ritual: An essay in comparative symbology. Rice University Studies 60(3): 53-92.

United Nations (1989) United Nations Convention on the rights on the child. Available at: http://www.ohchr.org/en/professionalinterest/pages/crc.aspx (accessed 30 November 2015).

Vervliet M, Vanobbergen B, Broekaert E, et al. (2015) The aspirations of Afghan unaccompanied refugee minors before departure and on arrival in the host country. Childhood 22(3): 330-345.

Watters C (2008) Refugee Children: Towards the Next Horizon. London: Routledge.

Wernesjö U (2012) Unaccompanied asylum-seeking children: Whose perspective? Childhood 19(4): $495-507$.

Wernesjö U (2014) Conditional belonging: Listening to unaccompanied young refugees' voices. PhD Thesis, Uppsala University, Uppsala.

Yuval-Davis N (2006) Intersectionality and feminist politics. European Journal of Women's Studies 13(3): 193209.

Yuval-Davis N (2011) The Politics of Belonging: Intersectional Contestations. Los Angeles, CA: SAGE. 